\title{
Field Report on the Excavation of Indian Villages in the Vicinity of the Spiro Mounds, Leflore County, Oklahoma
}

Kenneth G. Orr

Unknown

Follow this and additional works at: https://scholarworks.sfasu.edu/ita

Part of the American Material Culture Commons, Archaeological Anthropology Commons, Environmental Studies Commons, Other American Studies Commons, Other Arts and Humanities Commons, Other History of Art, Architecture, and Archaeology Commons, and the United States History Commons

Tell us how this article helped you.

This Article is brought to you for free and open access by the Center for Regional Heritage Research at SFA ScholarWorks. It has been accepted for inclusion in Index of Texas Archaeology: Open Access Gray Literature from the Lone Star State by an authorized editor of SFA ScholarWorks. For more information, please contact cdsscholarworks@sfasu.edu. 
Field Report on the Excavation of Indian Villages in the Vicinity of the Spiro Mounds, Leflore County, Oklahoma

\section{Creative Commons License}

(c) (1) (8)

This work is licensed under a Creative Commons Attribution-NonCommercial 4.0 International License 


\title{
FIELD REPORT ON THE EXCAVATION OF INDIAN VILLAGES IN THE VICINITY OF THE SPIRO MOUNDS, LEFLORE COUNTY, OKLAHOMA
}

\author{
Kenneth G. Orr
}

\begin{abstract}
A wealth of strikingly unusual and beautiful objects of Indian manufacture were excavated from the burials of the Spiro Mound, Leflore (sic.) County, Oklahoma during 1936-37. Engraved Gulf Coast conch shells, shell beads of a dozen types, river pearls, effigy pipes, long delicately chipped flint blades, feather and textile cloths and precisely incised pottery vessels were excavated in quantities. So unusual was this material that, at the time, the archaeological science was unable to answer a host of questions which immediately arose concerning the identity of the tribe who had made the artifacts and who were buried with them. How long ago had they occupied the region? From where had they come, and where did they go? The chronological relationship of the Spiro Mound Culture to the known cultures of the United States was of particular concern to the investigators. How and where did this tribe fit into the picture of America's past?
\end{abstract}

The answer to these important problems, and particularly to discount the theories of exotic origin, it was necessary to further investigate the region. The Works Progress Administration, under the direction of Dr. Forrest E. Clements and sponsored by the Universities of Oklahoma and Tulsa, continued archaeological excavation in the northern portion of Leflore County. Under the supervision of the writer more than 20 Indian villages have been excavated during the past year. A wealth of artifacts and archaeological data was unearthed during this time, and with it a fresh array of problems presented themselves.

As a field report, this paper will not attempt to put forth comprehensive solutions for the many archaeological problems encountered in Leflore County. Its purpose is rather to acquaint the reader with the nature of the features and materials coming from the Indian villages and the manner in which they are excavated and interpreted. Certain facts concerning the Spiro Mound culture, and the other cultures discovered in the region, have emerged from the work. However, since analysis and interpretation is at the present incomplete, the conclusions must be considered tentative and more in the nature of "leads" than of definitely established truths.

FIELD METHODS AND TYPES OF

FINDS: Indian villages are found in two 
situations - on terraced bottoms and on high bluffs overlooking rivers. An example of the first type of village site was discovered on the land of Spencer Littlefield, Braden, approximately two miles southeast of the Spiro Mound group. Here on a flat terrace, overlooking an extinct stream swale, a village composed of 20 houses was excavated. The site was nicely preserved from plow and erosion destruction by a stratum of river silt deposited by high waters of the Arkansas River. Below this silt blanket, house and burial features were found intact at a depth of from one to three feet. In direct contrast, most bluff sites have undergone considerable destruction due to plowing and sheet-water erosion. At the Bowman site, situated near the site of old Fort Coffee, 1.5 miles northwest of the Spiro Mounds, 12 houses were excavated. These houses occurred just below the plow line (six inches beneath the ground surface) and would have been completely eradicated in a few years. Some bluff sites have been eroded away. Such sites are generally characterized by the presence of considerable quantities of flint artifacts, sherds and burnt stones on the surface.

The finding of Indian village sites may appear to the uninitiated more a matter of "water-witching" than of scientific induction. Unfortunately there is no mysterious "mineral rod" involved in the discovery. At first glance a village site does not appear differentiated from the surrounding plowed fields. In practically all cases, however, there will be some surface indication of the village lying beneath the plowed furrows. Quantities of flint chips, fragments of pottery vessels and stone artifacts on a field surface generally mark a village site. In the bottom land villages, where silt deposits have covered the features, the indications will be less plain. Continuous plowing, nevertheless, exposes material even in bottom land sites. A small crew of specially trained workers, known as the survey crew, locates sites for the project. These men depend primarily on the cooperation of farmers, who report finding "a bucket full of arrow points", for their initial lead. Such information frequently leads to the discovery of a site. The survey crew furthermore knows the bottom land sites usually are to be fond at the junction of two streams and that bluff sites are invariably situated near springs. Likely locations may, with a high degree of accuracy, be plotted from a detailed contour map of the region.

The extent of a village is generally indicated in the area covered by surface debris (flint chips, sherds, etc.). The houses, however, usually lack any surface indications whatsoever. It has been thought the circular "mounds" (average height 2.5 feet, diameter 30 feet), which occur in groups of hundreds in Leflore County ${ }^{1}$, represented domiciliary mounds. The project's findings fail to support this theory. Many such mounds have been tested by trenching, but thus far, no trace of house-earth mixture or artifacts have been found. Houses must then be located

${ }^{1}$ [Ed. note: These are natural formations, perhaps erosional, and are termed by soil scientists as pimple, prairie, or mima mounds. 
by testing. Small test pits, two feet square and dug to the subsoil, are placed at 10 foot intervals over the entire village area. When a house-earth mixture is struck the indications are unmistakable.

Wood ordinarily decays away in the course of time, leaving no trace recognizable to the eye. Burned wood or charcoal, on the other hand, is as indestructible as stone. The majority of Indian houses had fortunately been burned. A house-earth mixture is impregnated with charcoal lumps and fallen posts, intermixed with wattle (the Indian wall and roof "plaster" of burnt clay), artifacts, animal bones and debris. Such earth mixtures vary in thickness from a few inches to 1.5 feet. The area covered by the house-earth mixture corresponds to the outline of the house. Since houses burn only down to the floor level, a good segment of the upright post, embedded in undisturbed subsoil, will not have charred. The embedded post will have decayed away and the post mould refilled with house-mixture. This important fact allows excavators to plot out post pattern or foundation plan of structure.

The post patterns of houses excavated by the Spiro Mound Project have been remarkably symmetric; all houses have straight rows of outside posts marking the walls of the structures (Plate 1). Outside posts are placed approximately a foot apart and vary in depth from six inches to 1.5 feet. Similarly, all houses have large internally situated posts, main roof supports and small secondary posts for the roof. Wattle has been found associated with the house sites, indicating by the grooves in the clay that the roofs were composed of rafters, twigs and reeds the inner surface of which had been coated with clay (wattle). The majority of the houses have a central fireplace. This is a circular or rectangular area of burnt clay on which is found white wood ash, split animal bones and charred vegetable debris. Occasionally, small caches or garbage pits are to be found in the corners. Common features of Leflore County houses indicate a basic relation-ship in house types. The small brush shelters of early Woodland phases found in Kansas and Nebraska, and the stone slab or adobe houses typical of the Southwest, are lacking in Leflore County. Though basically similar in materials used and technic (sic.) of construction, the house types are distinct in post pattern. Thus far, three well-defined house types and one sub-type have been excavated.

The importance of house types as an instrument for cultural diagnosis is clearly seen. It has been noted that houses of any village representing a single culture period are all of the same type. The architectural style of a culture at any time period

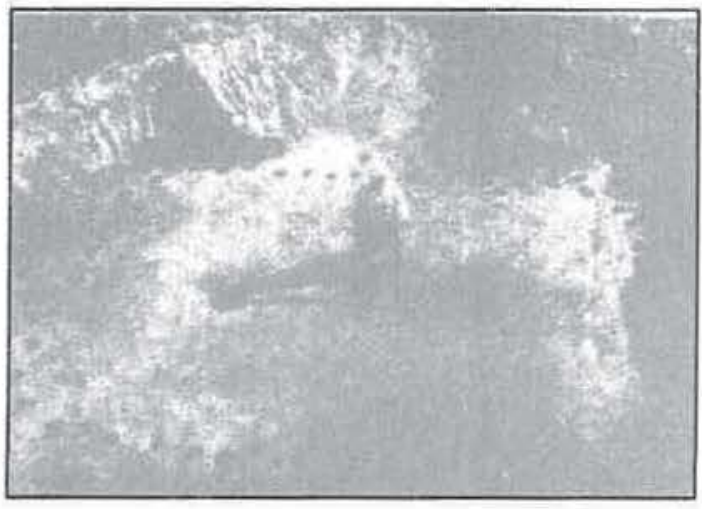

Plate 1. Plan of House Type I. 


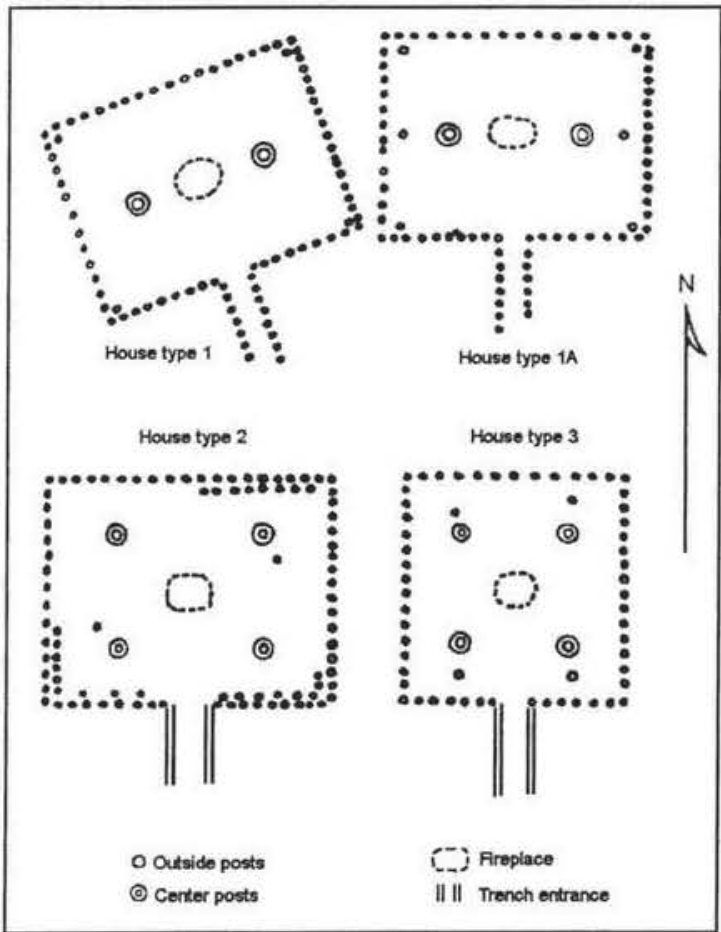

Plate 2. House types from LeFlore County, Oklahoma.

appears as distinct and well-defined as its ceramic decorative motifs. It would be well to briefly describe the house types (Plate 2) and indicated the correlation between house and artifact types:

HOUSE TYPE 1: A rectangular, two center post house, whose average dimensions are $18 \times 24$ feet. An entrance passage of parallel posts usually extends to the South. Type 1 is oriented with long axis either Northeast-Southwest or Northwest-Southeast, but never in the cardinal directions.

Pottery Associations: Shell tempered, porous brown and red slipped wares predominate. The average thickness is 0.2 inches. Vessel forms include: small and large mouthed ollas; small-necked water bottles; curved, straight and carinated bowls. Designs on this ware are elaborate, but in most cases have been scratched on after the vessel was fired. The motifs employed include: ladder, scroll, spur, negative circle, line-filled chevron, and punctated (Plate 3). The following structural elements are used as decoration: hollow protuberations filled with clay pellets (rattles), verticle (sic.) and horizontal rim tabs, ridge cameo designs, nodes, and scalloped rims. The incised ware is rare except in burials. The burials are of the flat type located near the village.

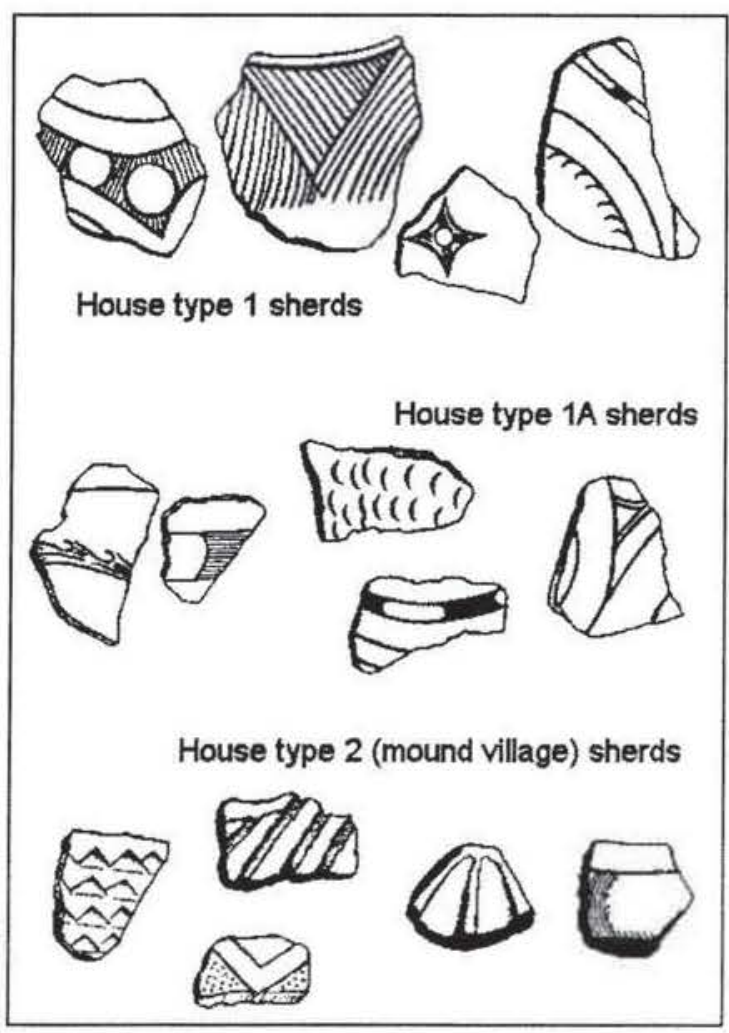

Plate 3. Decorative motif on sherds from LeFlore County, Oklahoma. 
Volume 11(3), October 2000

Other Artifacts: Tubular, limestone elbow pipes; long leaf-shaped knives; small, triangular, notched points; straight flint drills; sandstone metates and thin, rectangular manos are foufnd in the house-earth mixture.

Most of the villages thus far excavated were composed of type 1 houses. They have without exception been bluff site villages. The houses occur from 10 to 50 feet apart, but no definite "village plan" has been found.

HOUSE TYPE 1A: Similar to Type 1 except the houses are oriented in the cardinal directions. The long axis is oriented East-West, the short axis NorthSouth.

Pottery Associations: Shell tempered, hard, brown ware predominates. The surface of this ware is mainly polished. Smooth, red-slipped ware occurs. Sherd and grit tempering is found in small percentages. Though the decorative motifs used on the pottery are with few exceptions those of House Type 1, a real difference is noticed in the technic of incising. The majority of designs are neatly executed, haing been incised when the clay was firm. Bands of closely incised, parallel lines interrupted at intervals by negative ovals are found on poished black ware. These finely executed motifs are often filled with red pigment.

Other Artifacts: Stemless, tubular, limestone pipes; small triangular, notched points; ground-stone celts; sandstone shaft polishers; thin, ovoid manos and metates are found in the house-earth mixture.

One bottom-land village containing 20 houses of Type 1A has been excavated. Similar pottery has been found in other bottom-land village sites, but permission to excavate these for houses has not yet been secured.

HOUSE TYPE 2: This type is a rectangular, four center post house with an entrance passage to the South. The entrance consists of two parallel trenches. The type varies in size from $18 \times 24$ feet to $30 \times 40$ feet. Orientation is in the cardinal directions - long axis East-West. Baked, clay floors are common.

Pottery Associations: The pottery associated with House Type 2 is distinct from that associated with Types 1 and $1 \mathrm{~A}$. It is thick (average $0.5 \mathrm{inch}$ ), natural, dunorange ware tempered primarily with sherd, bone and sherd, or sherd and quartz grit. Vessels are extremely large, mouth diameters of 1.5 feet being not uncommon. This ware is mainly undecorated.

Other Artifacts: Small "bird" points, with plain or serrated edges; ear spool fragments; black stone beads; chipped stone hoes; polished stone celts; "T"shaped, large, tubular, limestone pipes; fragments of pottery platform pipes.

The one village containing houses of type 2 surrounds the Spiro Mound group, and is referred to as the Mound Village. Six houses have been excavated and 12 
more located. The village is approximately 0.75 mile long and 0.5 mile wide.

HOUSE TYPE 3: A square, four center post house, with entrance passage to the South. Similar to Type 2, the entrance consists of parallel trenches.

Pottery Associations: Bone and sherd tempered, smooth, brown ware has been found in association with Type 3.

Although house type 3 is a definitely established type, unique from types 1, 1A, and 2, so few have been found that the artifact characteristics of the culture phase represented is not clear. Only a few fragments of pottery vessels have been found in association. House of this type have all been found in bluff villages in close proximity with type 1 houses. Instances of house superposition make it clear the two types are not contemporaneous. Unfortunately, it has to date been impossible to determine which type originally occupied the site. The sherds found with type 3 are distinctly different from those of house type 1 , but closely resemble those of house type 2 (bone and sherd tempering).

It is possible that yet another type of house, a circular type, will be defined as a result of further work. A village site located at the north end of the Spiro Mound Village had produced two circular structures of 30 feet in diameter. No trace of center or secondary posts were found. The structure foundation had almost eroded away at the time of excavation, but the post circle was well-defined. This problematical structure was associated with shell hoes, pottery tubular elbow pipes, and a considerable amount of galena fragments. The pottery was of coarse shell-tempered hard ware of 0.3 inch average thickness. Diagonal dash incisings, cut in when the clay was soft, were located around a slightly collared rim. Dr. S.C. Dellinger, Archaeologist of the University of Arkansas, has noted a similarity between this ware and that of the Nodine Culture located in northeastern Arkansas.

A rectangular house with a hard-baked clay floor and red clay walls has been located on the river bluffs 4 miles southwest of the Spiro Mound site. A deplorable lack of cooperation on the part of the owner makes this unusual type unavailable for complete excavation and analysis. Superstition, cupidity and a firm belief that the true aim of the Project is to dig up "buried gold treasure" are the causes of such isolated cases of noncooperation. Altho (sic.) understandable, it is regrettable that scientifically valuable material should thus lie dormant - to be eventually demolished by plowing and erosion. It is probable, however, that more house types will be located in the course of the Project's work.

The confines of this paper do not allow a discussion of the burial grounds found associated with villages of house types 1 and $1 \mathrm{~A}$. From the burial grounds come the majority of the complete and restorable artifacts. Pottery found in house sites is, with rare exceptions, fragmentary. Flint and stone artifacts are also fragmentary. Each, however, is individually analyzed 
for traits of form, technic of manufacture and decoration. The statistical analysis of fragments as well as of complete specimens is of utmost importance in defining a culture and in determining its relation to other known cultures.

\section{INTERPRETATION OF ARTIFACT}

TYPES: The Chipped Stone artifact classification chart devised by Dr. W.D. Strong of Columbia University (Strong 1935) and widely employed in the Northern Plains region, is with minor modifications applicable to the points and other chipped artifacts found in Leflore County. A statistical count of flint projectile points by the use of the Strong classification system has led to interesting results. The small "bird" point (type SCa1), for example, appears confined almost entirely to the Mound Village. Similar points have been found in abundance in the Main Mound ("Great Temple") burials in association with the elaborate effigy pipes and incised conch shells. The triangular notched point (type $\mathrm{NBa} 1)$ appears restricted to villages containing house types 1 or $1 \mathrm{~A}$. The large shoulder point with receding tang stem (type SAa) is found associated with varying percentages with all villages. While the main burden in cultural diagnosis must fall on ceramic types, the importance of chipped flints maybe seen in the above brief example.

The form of pottery vessels, complete or fragmentary, is another important diagnostic study. This is particularly true since in Leflore County village sites incised ware is rare (though abundant in burials). Even fragmentary rim sherds possess three form features which lend themselves well to statistical treatment; namely, lip form, rim form and shoulder or body form. By a comparison of the morphological traits in the sherds of two distinct villages it is possible to determine the relationship between the villages. The Mound Village (house type 2), for example, is clearly not of the same culture phase as the Fort Coffee site (house type 1). Fully $60 \%$ of the Mound Village rim sherds are of the $5 \mathrm{Vb}$ type, i.e., olla forms possessing a rounded lip, vertical rim and gradually flaring shoulder. The Fort Coffee site is deficient in rim sherds of the $5 \mathrm{Vb}$ type; the largest percentage falling in the 10R4b type. This symbolically describes an olla form having a rounded roll (overhanging) lip, outflaring rim and gradually sloping shoulder. The relatively larger size of Mound Village vessels as compared with those of Fort Coffee further bears out this distinction.

All sherds (base, rim or body) may be counted for two traits; type of temper and type of ware. The statistical study of temper types has revealed interesting and highly significant results. The Mound Village, again, is clearly differentiated from the Fort Coffee site. Whereas the Mound Village (house type 2) temper is $80 \%$ ground up sherds, pottery from the Ft. Coffee site (house type 1) contains no sherd temper. Fully $65 \%$ of the sherds from the Ft. Coffee site are tempered with shell. The Littlefield site (house type 1A), however, contains a large percentage of shell and a small percentage of sherd temper. 
Other traits of ware, form, texture, thickness, and decorative motif indicate that the Littlefield site bears a relationship both to the Ft. Coffee site and to the Mound Village. In degree, the relation is considerably closer between the Littlefield and Ft. Coffee sites than between the Littlefield site and the Mound Village.

\section{*******}

CONCLUSIONS: The statistical approach not only allows a comparison of local sites, one with the other, but also allows a precise method of comparing local site material with that from other excavations. Such a comparison has been made with the cultures of Louisiana, excavated by James A. Ford in 1936 (Ford 1936). The pottery types excavated by Ford from historical Caddo villages bear a striking resemblance to those from house type 1 villages. Ford's Caddoan artifacts, however, are found in association with white trade material and are plainly historical, but no trace of historical material (such as glass beads, iron, etc.) Have been found in the villages. The lack of Caucasian trade material is felt to be due to lack of contact with white influence rather than incomplete excavation. This would suggest that the villages of house type 1 are probably associated with some phase of the Caddoan culture, possibly earlier than the historical tribes described Ford. A comparison of the Project specimens from house type 1 villages with those of Dr. Dellinger's Arkansas University collection further bears out the similarity between this pottery and that commonly called "Caddoan". Caution, however, must be used in employing the linguistic term "Caddoan" to sites on which documentary evidence is lacking. The non-historic house type 1 villages, however, plainly belong to a late phase of the lower Mississippi pattern. House type $1 \mathrm{~A}$ villages also appear related to a late phase of the Lower Mississippi pattern of perhaps an earlier period than the house type 1 villages. The relation of the Mound Villages to the features of the Main Mound ("Great Temple") is being determined at the present time by statistical analysis. It is felt that chronological problems of the Mound Village (house type 2) and the more elaborate features of the Main Spiro Mound are one and the same.

Whereas the pottery traits from house type 1 villages closely resemble what Ford has called Historic Caddo (see also Walker, 1935), the house type 2 or Mound Village pottery has some characteristics identical with the Cole's Creek prehistoric complex - an intermediate phase between the later phase and the basic Marksville complex of the Lower Mississippi pattern. Square base vessels, the presence of sherd and grit temper and typical Cole's Creek ceramic motifs (Plate 3 , a and b) indicate this relationship. Unfortunately, no house types associated with the Marksville-Cole's Creek-Caddo pattern have been published for comparative purposes.

A follow-up of the chronological leads arrived at through a comparative study, by statistical analysis, of artifact and house types will lead to scientifically correct 
facts concerning the cultures of Leflore County. Further excavation will, it is hoped, unearth stratified kitchen middens thus far singularly absent. Superposition of cultures ordinarily found in middens leaves no question as to the chronological position of the cultures. The problem of the roots and origin of the Main Mound culture has still to be answered. Though the roots of this culture are clearly seen to be in the Southeast, as a phase of the Lower Mississippi Pattern, no clear traces of an antecedent culture have been found by our Project thus far. Continued work may reveal an ancestral culture. Perhaps the square 4 center post houses represent an earlier and closely related peoples. The sequence of house types strongly suggest this, though the artifact contents of type 3 houses have been too meager to say more. Whatever the answer to the problems pointed out in this paper, and to those problems which will inevitably arise as the result of further work, it is felt a firm foundation has been established to cope with them, and to present the correct picture of Man's past in Eastern Oklahoma.

\section{REFERENCES CITED}

Ford, J.A.

1936 An Analysis of Potter Complexes in Louisiana. Anthropological Study \#2, Louisiana State Geological Survey.

Strong, W.D.

1935 An Introduction to Nebraska
Archaeology. Smithsonian Institute Miscellaneous Collection.

Walker, W.M.

1935 A Caddo Burial Site at Natchitoches, Louisiana. Smithsonian Institute Miscellaneous Collection 94(14). 